\section{Obesity - COVID-19 and Mechanical Ventilation of Intubated Patient}

\author{
Dalamagka Maria* \\ Department of Anesthesia, General Hospital of Larisa, Greece
}

Obesity as a disease causes a restrictive lung disease and is a sufficient predisposing factor for difficult ventilation of the patient in the ventilator. In addition to covid-19, the phenomenon of "hard lung" is observed as the ventilation of intubated patients is very arduous and recruitment requires a lot of effort. The combination is quite difficult as these patients oppose the ventilator. This paper aims to explore the link between obesity and mechanical ventilation in COVID-19 patients.

The prevalence of adult obesity and severe obesity in 2017 to 2018 has increased since 2009 to 2010 and is now $42 \%$ and $9 \%$, respectively [1]. Obesity is a global disease with at least 2.8 million people dying each year as a result of being overweight or obese according to the world health organization figures. Obesity is affecting most of the physiological processes and modifying the functions of the system including the immune system [2]. It is crucial to understand the effect of obesity on the course of infection to prevent or mitigate the morbidities and mortalit $[3,4]$. In the current COVID-19 era, bariatric teams are aware of the potential risks and thus stressing the extra caution and appropriate management of these patients [5]. Knowing the scale of the obesity problem in the world, we anticipate difficult times for this group of patients in Europe, America, Middle East and rest of the world with a high rate of obesity [6]. In 2009, a significant percentage of admissions to the hospitals and mortality because of H1N1 Influenza a virus infection was due to obesity, an estimated $151,700-575,400$ total deaths was reported $\mathrm{U}[7,8]$.

A 55-year-old man, with a body weight of $130 \mathrm{~kg}$ and active covid-19 was intubated and put into mechanical ventilation with model ACV, $\mathrm{FiO} 270 \%$ which gradually dropped to 50\%, PEEP 18 which gradually dropped to 14 , Tidal Volume $500 \mathrm{ml}$ which gradually

*Corresponding author: Dalamagka Maria, Department of Anesthesia, General Hospital of Larisa, Greece, Tel: +30 6979811407; E-mail: mary.dalamaga@gmail. com

Citation: Maria D (2020) Obesity - COVID-19 and Mechanical Ventilation of Intubated Patient. J Anesth Clin Care 7: 060.

Received: December 14, 2020; Accepted: December 25, 2020; Published: December 31, 2020

Copyright: $@ 2020$ Maria D, et al. This is an open access article distributed under the terms of the Creative Commons Attribution License, which permits unrestricted use, distribution, and reproduction in any medium, provided the original author and source are credited. dropped to $480 \mathrm{ml}$ and respiratory rate $30 / \mathrm{min}$ which gradually dropped to $25 / \mathrm{min}$, and I: E $1 / 2$ to $1 / 3$ and finally to $1 / 4$. Suppression of the patient was achieved by drip co-administration of Ultiva, Diprivan, Esmeron, Dormicum, and Levophed in titrated doses for the best possible ventilation of the patient. Obesity in combination with covid-19 leads to increased peak up to 60 and high airway resistance. Satisfactory dosing of Esmeron $60 \mathrm{mg} / \mathrm{h}$ and placement of low tidal volumes $<500 \mathrm{ml}$, as well as respiratory rate $<30 / \mathrm{min}$, PEEP $<16$, appears to improve ventilator ventilation when co-administered: Ultiva, Diprivan, Dormicum at satisfactory levels in combination with Levophed to maintain hemodynamic stability.

Thus it appeared that low respiratory rate $<30 / \mathrm{min}$ and low tidal volume $<500 \mathrm{ml}$ with a desired PEEP less than or equal to 14 , has a beneficial effect on obese patients.

\section{References}

1. Hales K, Carroll MD, Fryar CD, Ogden CL (2020) Prevalence of obesity and severe obesity among adults: United States, 2017-2018. NCHS Data Brief, no. 360: 1-8.

2. Fischer-Posovszky P, Moller P (2020) The immune system of adipose tissue: obesity-associated inflammation. Pathologe 41: 224-229.

3. Houdek MT, Griffin AM, Ferguson PC, Wunder JS (2019) Morbid obesity increases the risk of postoperative wound complications, infection, and repeat surgical procedures following upper extremity limb salvage surgery for Soft tissue sarcoma. Hand (N Y) 14: 114-120.

4. Zhou X, Ye Y, Tang G, Zhou X (2018) Obesity and infection, accompanying phenomenon or causal association? Clin Microbiol Infect 24: 668.

5. Dietz W, Santos-Burgoa C (2020) Obesity and its implications for COVID-19 mortality. Obesity (Silver Spring) 28: 1005.

6. Bluher M (2019) Obesity: global epidemiology and pathogenesis. Nat Rev Endocrinol 15: 288-298.

7. Louie JK, Acosta M, Samuel MC (2011) A novel risk factor for a novel virus: obesity and 2009 pandemic influenza A (H1N1). Clin Infect Dis 52: 301-312.

8. Dawood FS, Iuliano AD, Reed C (2012) Estimated global mortality associated with the first 12 months of 2009 pandemic influenza A H1N1 virus circulation: A modelling study. Lancet Infect Dis 12: 687-695. 


\section{Hif}

Advances In Industrial Biotechnology | ISSN: 2639-5665

Advances In Microbiology Research | ISSN: 2689-694X

Archives Of Surgery And Surgical Education | ISSN: 2689-3126

Archives Of Urology

Archives Of Zoological Studies | ISSN: 2640-7779

Current Trends Medical And Biological Engineering

International Journal Of Case Reports And Therapeutic Studies | ISSN: 2689-310X

Journal Of Addiction \& Addictive Disorders | ISSN: 2578-7276

Journal Of Agronomy \& Agricultural Science | ISSN: 2689-8292

Journal Of AIDS Clinical Research \& STDs | ISSN: 2572-7370

Journal Of Alcoholism Drug Abuse \& Substance Dependence | ISSN: 2572-9594

Journal Of Allergy Disorders \& Therapy | ISSN: 2470-749X

Journal Of Alternative Complementary \& Integrative Medicine | ISSN: 2470-7562

Journal Of Alzheimers \& Neurodegenerative Diseases | ISSN: 2572-9608

Journal Of Anesthesia \& Clinical Care | ISSN: 2378-8879

Journal Of Angiology \& Vascular Surgery | ISSN: 2572-7397

Journal Of Animal Research \& Veterinary Science | ISSN: 2639-375

Journal Of Aquaculture \& Fisheries | ISSN: 2576-5523

Journal Of Atmospheric \& Earth Sciences | ISSN: 2689-8780

Journal Of Biotech Research \& Biochemistry

Journal Of Brain \& Neuroscience Research

Journal Of Cancer Biology \& Treatment | ISSN: 2470-7546

Journal Of Cardiology Study \& Research | ISSN: 2640-768X

Journal Of Cell Biology \& Cell Metabolism | ISSN: 2381-1943

Journal Of Clinical Dermatology \& Therapy | ISSN: 2378-8771

Journal Of Clinical Immunology \& Immunotherapy | ISSN: 2378-8844

Journal Of Clinical Studies \& Medical Case Reports | ISSN: 2378-880

Journal Of Community Medicine \& Public Health Care | ISSN: 2381-1978

Journal Of Cytology \& Tissue Biology | ISSN: 2378-9107

Journal Of Dairy Research \& Technology | ISSN: 2688-9315

Journal Of Dentistry Oral Health \& Cosmesis | ISSN: 2473-6783

Journal Of Diabetes \& Metabolic Disorders | ISSN: 2381-201X

Journal Of Emergency Medicine Trauma \& Surgical Care | ISSN: 2378-8798

Journal Of Environmental Science Current Research | ISSN: 2643-5020

Journal Of Food Science \& Nutrition | ISSN: 2470-1076

Journal Of Forensic Legal \& Investigative Sciences | ISSN: 2473-733X

Journal Of Gastroenterology \& Hepatology Research | ISSN: 2574-2566
Journal Of Genetics \& Genomic Sciences | ISSN: 2574-2485

Journal Of Gerontology \& Geriatric Medicine | ISSN: 2381-8662

Journal Of Hematology Blood Transfusion \& Disorders | ISSN: 2572-2999

Journal Of Hospice \& Palliative Medical Care

Journal Of Human Endocrinology | ISSN: 2572-9640

Journal Of Infectious \& Non Infectious Diseases | ISSN: 2381-8654

Journal Of Internal Medicine \& Primary Healthcare | ISSN: 2574-2493

Journal Of Light \& Laser Current Trends

Journal Of Medicine Study \& Research | ISSN: 2639-5657

Journal Of Modern Chemical Sciences

Journal Of Nanotechnology Nanomedicine \& Nanobiotechnology | ISSN: 2381-2044

Journal Of Neonatology \& Clinical Pediatrics | ISSN: 2378-878X

Journal Of Nephrology \& Renal Therapy | ISSN: 2473-7313

Journal Of Non Invasive Vascular Investigation | ISSN: 2572-7400

Journal Of Nuclear Medicine Radiology \& Radiation Therapy | ISSN: 2572-7419

Journal Of Obesity \& Weight Loss | ISSN: 2473-7372

Journal Of Ophthalmology \& Clinical Research | ISSN: 2378-8887

Journal Of Orthopedic Research \& Physiotherapy | ISSN: 2381-2052

Journal Of Otolaryngology Head \& Neck Surgery | ISSN: 2573-010X

Journal Of Pathology Clinical \& Medical Research

Journal Of Pharmacology Pharmaceutics \& Pharmacovigilance | ISSN: 2639-5649

Journal Of Physical Medicine Rehabilitation \& Disabilities | ISSN: 2381-8670

Journal Of Plant Science Current Research | ISSN: 2639-3743

Journal Of Practical \& Professional Nursing | ISSN: 2639-568

Journal Of Protein Research \& Bioinformatics

Journal Of Psychiatry Depression \& Anxiety | ISSN: 2573-0150

Journal Of Pulmonary Medicine \& Respiratory Research | ISSN: 2573-0177

Journal Of Reproductive Medicine Gynaecology \& Obstetrics | ISSN: 2574-2574

Journal Of Stem Cells Research Development \& Therapy | ISSN: 2381-2060

Journal Of Surgery Current Trends \& Innovations | ISSN: 2578-7284

Journal Of Toxicology Current Research | ISSN: 2639-3735

Journal Of Translational Science And Research

Journal Of Vaccines Research \& Vaccination | ISSN: 2573-0193

Journal Of Virology \& Antivirals

Sports Medicine And Injury Care Journal | ISSN: 2689-8829

Trends In Anatomy \& Physiology | ISSN: 2640-7752

Submit Your Manuscript: https://www.heraldopenaccess.us/submit-manuscript 